e-ISSN: 2686-522X, p-ISSN: 2686-5211

DOI: https://doi.org/10.38035/jafm.v1i5

Received: 07 October 2020, Revised: 18 October 2020, Publish: 06 November 2020

https://creativecommons.org/licenses/by/4.0/

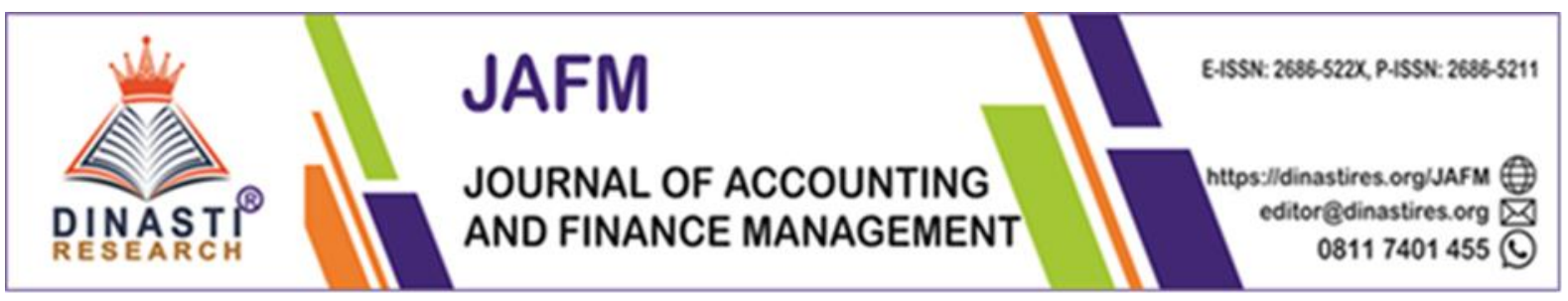

\title{
Wage Policy Impact on Employee Performance in Industry Areas Bekasi District
}

\author{
Sabil Sabil ${ }^{1)}$ Mohamad Syamsul Maarif ${ }^{2)}$, Edie Toet Hendratno ${ }^{3)}$, Widarto Rachbini ${ }^{4)}$ \\ ${ }^{1)}$ University Pancasila, Indonesia, sabil.sbl@bsi.ac.id \\ ${ }^{2)}$ University Pancasila, Indonesia, syamsu14958@gmail.com \\ ${ }^{3)}$ University Pancasila, Indonesia \\ ${ }^{4)}$ University Pancasila, Indonesia, widarto@rachbini.com
}

Corresponding author: Sabil Sabil ${ }^{1}$

\begin{abstract}
In the last few years, employee performance has decreased because the wages received are considered insufficient to meet the needs of a decent life. The purpose of this study was to examine and analyze those influencing wage policies and employee performance in companies in the Bekasi Regency industrial area. The study population was employees of companies in the industrial area of Bekasi Regency. In accordance with structural equition modeling (SEM), a sample of 285 respondents was selected through a purposive sampling technique. Data analysis was applied by applying government regulation theory, trade union theory, labor productivity theory, wage policy theory and employee performance theory. Hypothesis testing was carried out using SEM with the Lisrel Version 8.80 application. The results showed that the direct effect of government regulations, labor unions, work productivity and living costs has a significant effect on wage policies and government regulations, labor unions, wage policies have a significant effect on employee performance and indirect effects. government regulations, labor unions, work productivity, cost of living, have a significant effect on employee performance through wage policies.
\end{abstract}

Keywords: Government Regulations, Trade Unions, Work Productivity, Cost of Living, Employment Policy, Employee Performance

\section{INTRODUCTION}

Wage policy issues are important for both employees and organizations. Payers to employees must have a logical and rational basis. The amount of wages received by employees is a reflection or a measure of the work value of the employees themselves, the size of the wages can affect employee performance, if the direct compensation (Wages) is inadequate or inappropriate, the employee's performance will decrease "(Notoatmojo, 2003 : 153). If the company expects an increase in employee performance, it is also necessary to pay 
attention to the level of wages in accordance with the determined standards, because if the company sets wages that are not in accordance with standards that are not sufficient for a decent living, it will have an impact on the decline in employee performance. Each company determines the amount of wages paid to employees must be appropriate so that these wages can meet their daily needs (Kanzunnudin, 2007). According to (Indrasari Tjandraningsih, 2009 ) that the average wage received by employees is only $80 \%$ of the needs of a decent life. so that the effect is that employees go on work strikes and do demonstrations to demand a wage increase, wages are an important issue for employees and organizations. Paying wages to employees must have a logical and rational basis. The amount of wages received by employees is a reflection or a measure of the work value of the employee itself, the size of the wages can affect employee performance, if the wages are inadequate or inappropriate, then the employee's performance will decrease, according to (Noto Atmodjo, 2003) low will have an impact on decreasing the attractiveness of work and ultimately will have an impact on the decrease in karyan performance. In order for employee performance to continue to increase, it is necessary to establish policies that are acceptable to workers, employers and the government. According to (Nurhidayati, 2016) In order for employee performance to remain good and increase, it is necessary to establish a wage policy that is agreed upon between the government, trade unions and employers.

Wage policies are influenced by government regulations, trade unions, employee productivity and the cost of living. According to (Edy Sutrisno, 2009) Wage policies will be influenced by: Government regulations relating to manpower in Indonesia with invitation 13 of 2003 in Article 88 explicitly indicating the function of wages as a means of achieving a decent life, the government is obliged to make legal policies regarding financial compensation (Wages). The role of trade unions in fighting for their members to get a decent wage, research (Kurniawan \& Sulistyaningrum, 2017), the results show that on average, private sector workers in Indonesia who participate as members of labor unions will have a higher wage by $17 \%$ compared to workers who are outside the labor union. Research (RiosAvila, 2013) using the Recentered Influence Functions Regression method concluded that for the Latin American region, trade unions have a positive impact on the wage levels of their members. The results of the study (Frandsen, 2012) concluded that for the case in the United States, labor unions had a positive impact in the form of increasing the lower limit of individual income distribution by 30 Log points.

The determination of the wage rate is based on the productivity that labor produces from the specified unit of time. The relationship is more reciprocal, if labor productivity increases, the wage rate will also increase so that real wages will rise, the results of research (Ketut Alit Wiantara, 2015) show that productivity affects the wage level. (Klein, 2012) conducted research on the relationship between real wages and work productivity using panel data analysis between South Africa and several emerging and developed countries. shows that real wages have a positive and significant relationship to productivity in the long run. (Adnan \& Saragih, 2019) the results of their research with a variable regression coefficient of work productivity (X2) of 0.284 , meaning that if work productivity is increased by 1 (unit), employee performance has increased considerably, amounting to 0.284 units. The coefficient is positive, meaning that there is a unidirectional relationship between work productivity and employee performance. 
Cost of living according to the Decree of the Minister of Manpower No. 17 of 2005 concerning the components and implementation of the stages of achieving proper living needs, it is stated that the Decent Living Needs, hereinafter abbreviated as KHL, are the standard needs that must be met by a single worker / laborer to be able to live properly, both physically and non-physically and socially for the needs 1 (one month. KHL as the basis for determining the minimum wage is an increase from the minimum living needs. The KHL value is obtained through a price survey. The determination of the provincial minimum wage is based on the lowest district / city decent living needs (KHL) value in the province concerned by using productivity and economic growth. In determining the stages of achieving the KHL, the Governor takes into account the conditions of the job market, in the Province / Regency / City. According to (Michael C. Sturman et al., 2017) that the cost of living has a positive effect on the level of financial compensation, namely in the form of wages, but for workers at high levels it does not have a positive effect. According to (Winters, 2009) "the necessities of life quite influence the level of wages because due to certain location differences have higher prices for goods and services that provide a certain level of utility, workers will need higher wages to work there".

\section{LITERATURE REVIEW}

\section{Wages Policy}

Wages and salaries are generally given for performance that has been carried out based on established performance standards or mutually agreed upon based on a personal contract. (Sukirno Sadono, 2013) defines wages as payment wages obtained from various forms of services provided and provided by workers to entrepreneurs. Medium (T. Gilarso, 2003) defines wages as remuneration for human labor production factors, which include salaries, honoraria, overtime pay, allowances, and others. According to (Mulyadi, 2001), salaries and wages are generally payments for services made by employees who have the ranks, managerial positions, and on a monthly divorce basis, while wages are payments for the delivery of services made by implementing employees (laborers) which are based on days. work, hours worked, or the number of product units produced by employees. In PP $78 / 2015$, it is stated that the wage policy is directed at achieving an income that fulfills a decent living for workers / laborers. Decent income as meant by this regulation is the amount of revenue orincome of the worker / laborer from the result of his work being able to meet the living needs of the worker / laborer and his family fairly The decent income policy referred to in PP 78/2015 is provided in the form of Wages and Non-Wage Income.

\section{Government Regulations}

Government regulations are to protect workers or employees from the arbitrariness of the employer, so that the government in this case has the authority to determine the minimum wage, working hours, age limits so that the welfare of employees and society in general can be achieved. According to (Kirdi Dipoyudo, 2005) Government participation in setting wage standards is: 1 . To advance the workforce. 2. To protect working groups that receive very low wages, 3 . To encourage the provision of appropriate wages. 4. To create calm at work 5. To Encourage the improvement of living standards. (Simon, 2007) as an objective or subjective, deliberate, and organizational decision. Furthermore, Robbins' rational decision formulation in (Wahyuningtyas, 2014) is by 
knowing public preferences and tendencies, finding choices, knowing the consequences of each choice, assessing the ratio of social value sacrificed, and choosing the most efficient alternative policy.

According to (Megawati Maulidyah Jaenudin \& Alini Gilang, 2015) Based on the results of the research and analysis that has been done, it can be concluded that what can provide answers to the problems in the formulation of this research is that government regulations are the most dominant factor influencing wage policies.

\section{Workers Union}

A Worker / Labor Union is an organization formed from and by workers / laborers. Thisorganization is useful for fighting for, defending and protecting the rights and interests of labor workers. The formation of a Trade Union / Labor Union organization is in the context of improving the welfare of workers / labor. Work has the right and freedom to participate in a trade union organization which it desires. In Indonesia the freedom to become a member of an organization which is the choice of workers, related to the company, business sector or a particular area.

According to (Budiarti, 2008) the role of trade unions is the ability of trade unions to provide protection, defend rights and interests, resolve disputes, communicate information. and improve the welfare of workers and their families. (Boje, 2003), trade unions in various countries have at least three functions, namely: 1) a trade union is an institution that negotiates with employers about wages and working conditions; 2) trade unions are part of a social movement that aims to improve the living conditions of workers; and 3) trade unions are pressure groups that influence parliament, government and public administration.review in an arrangement of scientific papers can be interpreted as an affirmation of the limitations of scientific work. The digest in this section is contained in full in the keyoword in the abstract section. Therefore, the preparation of any written works must be obliged to make a literature study.

\section{Work Productivity}

According to (Yuniarsih Tjutju, 2009), "work productivity can be interpreted as a concrete result (product) produced by individuals or groups during a certain unit of time in a work process."According to (Sedarmayanti, 2004) "productivity is how to produce or increase the highest possible output of goods and services by utilizing human resources efficiently. Productivity is an achievement of the work of employees in an effort to achieve the organizational goals that have been set ". According to (Umar, Husen, Dr, 2008) "Productivity means a comparison between the results achieved (output) with the overall resources used (output)."According to (Sutrisno, 2009) "Stating that the notion of productivity is generally defined as the relationship between output (goods or services) and input (labor, materials, money)"

\section{Cost of Living}

According to (Mankiw n Gregory, 2006) the calculation of the cost of living is the speed / step-by-step instructions on how to calculate the cost of living, where we as humans will know about economic planning in households or in everyday life and as a need we need to find a way to convert cash. The task performed by statisticians and referred to as the consumer price index. After measuring user prices, we'll cover how to use a price index to calculate money in time. 1. An aspect that is calculated in the 
consumer price index Food and beverage, housing, transportation, education and communication, health care, recreation, equipment, goods and other services. 2 . With the price index. Related to the consumer price index is the emergence of new goods. When there are new items on the market, consumers will have more choices. Furthermore, more choices will increase the value for money, so that consumers need less money to maintain their standard of living. Because the consumer price index requires less money to maintain their standard of living. Because the consumer price index is calculated based on a fixed basket of goods and services, it cannot reflect changes in purchases.

\section{Employee Performance}

In performance, it discusses matters relating to the performance measurement system, the basis for performance measures, performance measurement criteria, characteristics, and thinking frameworks. According to (Dessler, 2000; 41) "Performance is a work achievement, namely the comparison between work results with a set standard." According to(Mangkunagara, 2002: 22) "Performance is the result of work both in quality and quantity achieved by a person in carrying out a task. according to the responsibility given ". Accordingto (Rivai \& Basri, 2005) Performance is the result or level of success of a person as a whole during a certain period in carrying out a task compared to various possibilities, such as standard work results, targets or targets or criteria that have been determined in advance and have been mutually agreed ". According to (Mathis \& J.H. Jackson, 2006) "states that performance is basically what employees do or don't do. Performance management is all activities undertaken to improve the performance of a company or organization, including the performance of each individual and work group in the company. "

According to (Mangkunegara, 2005) "Performance in quality and quantity achieved by an employee in carrying out his duties in accordance with the responsibilities assigned to him". According to (Hakim, 2006) "performance as a result of work achieved by an individual that is adjusted to the role or task of the individual in a company in a certain periodof time, which is associated with a certain measure of value or standard of the companywhere the individual works."

\section{RESEARCH METHODS}

In this study, there were 285 respondents in this study. The sampling technique used in this study was nonprobability sampling with a purposive sampling method. The criteria for respondents who were taken as samples were respondents who worked for companies in the industrial area of Bekasi district. The data collection technique was done using a questionnaire questionnaire. The questionnaire contains written statements for respondents to be given answers. According to (Sujarweni, 2014) The questionnaire is a data collection technique which is done by giving a set of questions and written statements to respondents. For this reason, the authors use a Likert scale to measure respondents' answers with a Likert scale of 1- 5. Data analysis comes from the data collection results. Because the data that has been collected, if it is not analyzed, will only become meaningless, meaningless items, become dead data, and data that do not sound. Therefore, data analysis here serves to convey the meaning, meaning and value contained in the data (Kasiram, 2006). To determine the direct effect, namely the effect of government regulations, labor unions, work productivity, 
the cost of living on wage policies and the direct influence of government regulations, trade unions and wage policies using SEM (Structural Equation Modeling) analysis method with lisrel. 8.80 with the Fit Analysis of the Measurement Model, CFA Test of Variables, Evaluation of the Validity and Reliability of the Measurement Model, Validity and Reliability Test, Goodness of Fit (GOF) Match Test, (Rachbini \& Didik J. Rachbini, 2020), as well as the effect of direct action, namely, regulation government, labor unions, work productivity, cost of living on employee performance through wage policies using SEM Lisrel with Sobel Test, in this single test is used to determine the effect of the mediating variable.

\section{FINDINGS AND DISCUSSION}

In this study, there were five hypotheses tested and based on the test results, the results were:

Table. 1. Testing the Research Model Hypothesis

\begin{tabular}{|c|c|c|c|}
\hline Hypothesis & Hypothesis statement & T-Value & Information \\
\hline $\mathrm{H} 1$ & $\begin{array}{lll}\text { Government regulations have } & \text { a } \\
\text { significant effect on Wage Policy }\end{array}$ & 2,17 & $\begin{array}{l}\text { The data support the } \\
\text { hypothesis }\end{array}$ \\
\hline $\mathrm{H}_{2}$ & $\begin{array}{l}\text { Worker Unions have a significant } \\
\text { effect on Wage Policy }\end{array}$ & 3,32 & $\begin{array}{l}\text { The data support the } \\
\text { hypothesis }\end{array}$ \\
\hline $\mathrm{H} 3$ & $\begin{array}{l}\text { Work productivity has a significant } \\
\text { effect on Wage Policy }\end{array}$ & 3,10 & $\begin{array}{l}\text { The data support the } \\
\text { hypothesis }\end{array}$ \\
\hline $\mathrm{H} 4$ & $\begin{array}{l}\text { The cost of living has a significant } \\
\text { effect on wage } \\
\text { policies }\end{array}$ & 9,74 & $\begin{array}{l}\text { The data support the } \\
\text { hypothesis }\end{array}$ \\
\hline H5 & $\begin{array}{l}\text { Government regulations have a } \\
\text { significant effect on employee } \\
\text { performance }\end{array}$ & 2,02 & $\begin{array}{l}\text { The data support the } \\
\text { hypothesis }\end{array}$ \\
\hline H6 & $\begin{array}{l}\text { Workers Union has a significant effect } \\
\text { on Employee Performance }\end{array}$ & 3,31 & $\begin{array}{l}\text { The data support the } \\
\text { hypothesis }\end{array}$ \\
\hline $\mathrm{H} 7$ & $\begin{array}{l}\text { Wage Policy has a significant effect on } \\
\text { Employee Performance }\end{array}$ & 3,19 & $\begin{array}{l}\text { The data support the } \\
\text { hypothesis }\end{array}$ \\
\hline $\mathrm{H} 8$ & $\begin{array}{l}\text { Government regulations } \\
\text { significant effect on ave a } \\
\text { Performance through Wage } \\
\text { Policies }\end{array}$ & 1.8 & $\begin{array}{l}\text { The data support the } \\
\text { hypothesis }\end{array}$ \\
\hline H9 & $\begin{array}{l}\text { Worker Unions have a significant } \\
\text { effect on Employee Performance } \\
\text { through Wage } \\
\text { Policies }\end{array}$ & 2.3 & $\begin{array}{l}\text { The data support the } \\
\text { hypothesis }\end{array}$ \\
\hline $\mathrm{H} 10$ & $\begin{array}{l}\text { Work Productivity has a significant } \\
\text { effect on Employee } \\
\text { Performance through WagePolicy }\end{array}$ & 2.2 & $\begin{array}{l}\text { The data support the } \\
\text { hypothesis }\end{array}$ \\
\hline $\mathrm{H} 11$ & $\begin{array}{l}\text { Cost of Living has a significant effect } \\
\text { on Employee Performance } \\
\text { through Wage Policy }\end{array}$ & 3.0 & $\begin{array}{l}\text { The data support the } \\
\text { hypothesis }\end{array}$ \\
\hline
\end{tabular}

\section{The influence of government regulations on wage policies.}

In the results of testing the first hypothesis (H1), it was found that the results of the analysis support the $\mathrm{H} 1$ hypothesis, namely that government regulations have a significant 
effect on wage policies, because the T-value is $2.17>1.96$. From the results of this test it shows that government regulations have an effect on wage policies. . This means that when government regulations change, they will cause significant changes to wage policies. Whereas government regulations on wage policies for Indonesia are very dominant, wage policies are regulated by the government, so the wage policy through the Manpower Law is always changing and increasing the determination of the Regional Minimum Wage, according to (Kirdi Dipoyudo, 2005) Government participation in setting wage standards is topromote labor. work, protecting work groups that get very low wages, encouraging the provision of appropriate wages, creating peace in work, encouraging an increase in living standards, but if viewed from the entrepreneur, the wage policy with government regulations will also have an impact on the company's ability to receive these changes, because companies that accept these changes but also ask to postpone changes to wage policies or may leave the industrial area. Government regulations function to regulate the relationship between employers and workers. Government regulations are needed as an intermediary in the event of a dispute between employers and workers as well as the involvement of the Bekasi Regency government in an effort to establish wage policies, that in determining wage policies the Bekasi Regency government plays a role in determining the amount of wages that apply to industrial estates in Bekasi Regency. The Regent has the opportunity to improve existing workers in his area because they better understand the capacity of the region and also the capacity of the company, thereby increasing wages according to existing capabilities, the process of discussing and conducting surveys by the Wage Council can be balanced by the role of quality control of the Regent / Mayor, which can approve or not the formula produced by the Wage Council based on certain considerations. The governor or regent / mayor can use their authority to reclaim the minimum wage requested by the Wage Council to be reformulated. If within 14 (fourteen) days there is no response, the governor or regent /mayor has the authority to get the minimum wage. This shows that the role of the government through regulations is to be able to determine the size of the steam level that applies in BekasiRegency.

\section{The influence of trade unions on wage policies}

In the results of testing the first hypothesis $(\mathrm{H} 2)$, it was found that the results of the analysis supported the $\mathrm{H} 2$ hypothesis, namely that labor unions had a significant effect on wage policies, because the T-value was 3.32> 1.96. The results of this test indicate that labor unions have an effect on wage policies. This means that when the union is able to negotiate well with the company, it will cause significant changes to wage policies. The role of trade unions in defending and demanding both the government and the companies they work for, for changes in wage increases. According to (Budiarti, 2008) the role of trade unions is the capability or ability of trade unions to provide protection, defend rights and interests, resolve disputes, communicate information and improve the welfare of workers and their families. Changes in wage policy are mostly carried out by trade unions by mediating with wage councils or by emphasizing demonstrations so that changes in compensation are even better. According to (Qianqian Huang et al., 2017), that the influence of labor unions is quite strong, negotiations between trade unions and companies will influence decisions at the cooperative level. And according to (Geby Alvita et al., 
2014), the role of trade unions is considered goodbecause it has a positive and significant effect on employee welfare. Companies in the BekasiRegency industrial area also have the same role as other labor unions, namely playing a defensive role in increasing the income of their members by applying good pressure to the government, which in this case has a role in making policies in determining the level of compensation as well as trade unions to emphasize companies to always pay attention towage levels.

\section{Effect of work productivity on wage policies.}

In the results of testing the first hypothesis (H3), it was found that the results of the analysis supported the $\mathrm{H} 3$ hypothesis, namely that work productivity had a significant effect on the determination of compensation, because the T-value was $3.10<1.96$. The results of this test indicate that work productivity has a significant effect on Wage Policy. This means that when work productivity changes, it can cause significant changes to wage policies. In theindustrial area in Bekasi Regency work productivity can have a significant effect on wage policies. According to the Regional Productivity Development Center (Umar, 2001), there are six (6) main factors that determine labor productivity, namely; Work attitude, skill level, relationship between labor and leadership, workforce efficiency. For the work efficiency industrial area, the skill level has been determined through the labor law as a whole, the company only follows the manpower law. According to (Anoraga, 2009) the level of a person's work productivity is influenced by several factors including: motivation, education, work discipline, skills, work ethic, income level, work environment and work climate, technology, production facilities, social security, management, opportunities for achievement. Measurement of labor productivity is a management tool at all levels of the economy. Work productivity is used to help evaluate appearance, planning, income, wages and price policies through the identification of factors that affect the distribution of income. Productivity measurement is mainly used as a management tool to analyze and promote production efficiency. Another benefit is setting targets, as well as benchmarks in paying employee wages. In general, the types of work can be divided into two, namely production jobs and non-production jobs. According to (Handoko, 2006), the measurement of labor productivity can be found with the formula: Labor productivity $=$ number of products produced / working hour. decreased or increased productivity can be used by companies to provide intensive. In companies in the industrial area of Bekasi Regency, the government has set a wage policy in the form of a Provincial or District Minimum Wage. Work productivity is one that influences wage policy setting. Work productivity significantly affects the determination of wage policies in companies in the industrial area of Bekasi Regency, this shows that if work productivity is high it will affect the determination of wage policies in the determination of the next period or the following year and the determination of wages will follow work productivity, namely wages will increase.

\section{Effect of the Cost of Living on wage policies.}

In the results of testing the first hypothesis (H4), it is found that the results of the analysis support the $\mathrm{H} 4$ hypothesis, namely the cost of living has a significant effect on the determination of compensation, because the T-value is 9.74> 1.96. . This means that when the Cost of Living changes, it will cause significant changes to the wage policy. According to(Michael C. Sturman et al., 2017) The cost of living has a positive effect on 
the level of financial compensation, namely in the form of wages, but this only affects the operational level or the level of production, but for employees at manager level this has less or less positive effect. For this reason, it turns out that the cost of living also greatly influences the determination of compensation. In companies in the Bekasi Regency Industrial Estate, the cost of living in Bekasi Regency is considered quite high, such as ownership of a residential house, that the wages received are not enough to buy a house or place to live because the price is quite high, not to mention the cost of food, transportation and so on. so, the cost of living greatly encourages the establishment of an even more ideal wage policy. Changes in the cost of living as a result of inflation or an increase in the price of basic necessities will be followed by adjustments of wage policies based on the existing inflation rate in the following year or the wages will increase.

\section{The influence of government regulations on employee performance}

In the results of testing the seventh hypothesis (H5), it is found that the results of the analysis support the hypothesis (H5), namely that government regulations have a significant effect on employee performance, because the T-value is 2.02> 1.96. Employee performance. This means that when government regulations change, it will cause significant changes to employee performance. Labor Law No. 13 of 2003, which regulates the rights and obligations of labor-related laws, namely this labor law was formed on the basis of the desire to develop the world of labor in Indonesia. With the aim of optimally empowering the workforce, opening up equal employment opportunities, providing protection for workers, and improving their welfare. One of the government policies in determining Indonesian wages is aimed at protecting employees from arbitrariness by employers, so that a fair wage level is determined. Nowadays, employers / employers rarely pay attention to the needs of their workers, and instead they usually always seek maximum profit to enrich themselves. Meanwhile, employees are given low wages. In order to avoid abuse and oppression, and to create prosperity, the state (government) must pay attention to the minimum wage that employers must pay to their workers, because the welfare of society is very important for social and state stability. The aim of the government to participate in regulating and setting wage standards is to prevent exploitation and exploitation of workers by employers. The aim is to protect groups of workers from low wage levels, so that the wages set by the employer can provide satisfaction, as well as to achieve employee employment and improve living standards. In addition to determining the level of wages, the government also stipulates occupational health and safety (K3), which is an activity that ensures the creation of safe working conditions, is protected from physical and mental disorders through guidance and training, directs and controls the implementation of employee duties and provides assistance in accordance with the regulations applicable, both from government agencies and companies where they work (Yuli, 2005) Companies naturally have a strategy to minimize or even eliminate the incidence of accidents and occupational diseases among employees in accordance with company conditions (Ibrahim JK \& Ismi D, 2010).

\section{The influence of trade unions on employee performance}

In the results of testing the eighth hypothesis (H6), it is found that the results of the analysis support the hypothesis (H6), namely that labor unions have a significant effect on employee performance, because the T-value is 4.67> 1.96. From the results of this test it 
shows that the union has an effect on employee performance. This means that when the union is able to negotiate well with the company, it will cause significant changes to employee performance. Wages or salaries are the rights given by the company to employees to work and the responsibilities given for a certain period of time. Meanwhile employee performance is the employee's job for the job and their responsibilities have been assigned by the employees to the company. If employee rights are granted by large companies, it can be a tool to motivate employees at work and improve their performance in realizing company goals. According to (Nadziroh et al., 2017) Salary determination has a positive effect on employee performance so that it can be concluded that there is an increase in employee performance through salary determination. From the overall research results, it shows that the determination of salary has a positive and significant effect on employee performance. This research also shows that the role of trade unions in improving employee performance is quite significant, meaning that the union does not only prosecute changes in wage level policies, but also plays a role in improving employee performance through its active role in encouraging its members to improve their performance, if they want higher changes in the income of their members.

7. The effect of wage policies on employee performance.

In the results of testing the sixth hypothesis (H6), it is found that the results of the analysis support the H6 hypothesis, namely that wage policy has a significant effect on employee performance, because the T-value is $3.19<1.96$. The results of this test indicate that the wage policy has a significant effect on employee performance. This means that when the wage policy changes, it causes a significant change in employee performance. According to (Efendi \& Sastra Tamami, 2017) The higher the level of wages given by the company, the greater the morale of the company's employees. Employees will be motivated to be enthusiastic about working because the company is considered capable of adjusting the level of wages to obtain decent living needs (KHL).

The results of the study (Havidatun Nadziroh Al Ghozali and Sandi Eka Suprajang, 2017) have a positive effect showing that the higher the wage setting, the higher the employee's performance. Determination of the amount of wages or more broadly remuneration or compensation, is related to the quality of employees owned by the company. Based on the research results, it can be concluded that the wage setting variable has a significant effect on employee performance. The results of this study indicate that the wage policy has a significant effect on employee performance, that changes in wage policy in accordance with the needs of a decent life will increase employee performance, therefore if employee performance is getting better or increasing, it is necessary to make improvements to wage policy, because according to Previous researchers, the higher the level of wages that employees get, the employee performance will also increase.

\section{The Influence of Government Regulations on Employee Performance through wage policies}

In the results of testing the eighth hypothesis (H8), it is found that the results of the analysis support hypothesis H8, namely that Government Regulation has a significant effect on Employee Performance through Wage Policy, because the T-value is 1.794> 1.280 (significant at the $10 \%$ level). From the results of this test, it shows that the influence of Government Regulation on Wage Policy shows significant at alpha 5\% and 
Wage Policy on performance also shows significant at alpha 5\%. The influence of the mediating variable between the two variables can be confirmed from a single test which shows the mediation between Government Regulations and Employee Performance through Wage Policies. This means that when the wage policy changes, it can cause significant changes to the effect of Government Regulations on employee performance. So that in this study shows that government regulations can encourage employee performance improvement through wage policies. If the wage policy is implemented in accordance with government regulations, it will indirectly increase the performance of employees who are in companies in the industrial area of Bekasi Regency.

\section{The influence of labor unions on employee performance through wage policies}

In the results of testing the eighth hypothesis (H9), it is found that the results of the analysis support the H9 hypothesis, namely that the Worker Union has a significant effect on Employee Performance through Wage Policy, because the T-value is 2,300> 1,965 (significant at the 5\% level). From the results of this test, it shows that the influence of labor unions on wage policies is significant at alpha $5 \%$ and wage policies on performance also show significant at alpha 5\%. The influence of the mediating variable between the two variables can be confirmed from a single test which shows that there is a mediation between the Worker Unions and the Employee Performance through the Wage Policy. That trade unions can indirectly improve employee performance through demands for changes to better wage policies. If the wage policy is determined fairly, it will cause significant changes in employee performance. So that in this study shows that the union can encourage employee performance improvement through wage policies.

\section{Effect of Work Productivity on Employee Performance through wage policies}

In the results of testing the eighth hypothesis (H10), it is found that the results of the analysis support the H10 hypothesis, namely Work Productivity has a significant effect on Employee Performance through Wage Policy, because the T-value is 2,223>1,965 (significant at the 5\% level). From the results of this test, it shows that the effect of work productivity on wage policy shows significant at alpha $5 \%$ and wage policy on performance also shows significant at alpha 5\%. The influence of the mediating variable between the two variables can be confirmed from the single test which shows the mediation between Work Productivity and Employee Performance through Wage Policy. This means that work productivity can affect employee performance indirectly through wage policies, if the wage policy changes higher, it can cause significant changes to employee performance. So that in this study shows that work productivity can encourage employee performance improvement through wage policies.

\section{The effect of the cost of living on employee performance through wage policies.}

In the results of testing the eighth hypothesis (H11), it is found that the analysis results support the $\mathrm{H} 11$ hypothesis, namely that the cost of living has a significant effect on Employee Performance through Wage Policy, because the T-value is 3.032> 1.965 (significant at the 5\% level). From the results of this test, it shows that the effect of the cost ofliving on the Wage Policy shows significant at 5\% alpha and the Wage Policy on performance also shows significant at 5\% alpha. The effect of the mediating variable between the two variables can be confirmed from the single test which shows the mediation between the cost of living on employee performance through the Wage 
Policy. This means that the cost of living can affect employee performance indirectly, namely through wage policies, if the wage policy is in accordance with the needs of a decent life, it can cause significant changes to employee performance. the need for a decent life is the demands of employees on companies in the industrial area of Bekasi Regency. Because in Bekasi the cost of living is getting higher, the demands for wage level adjustments must refer to the fulfillment of the needs for a decent life, if the needs for a decent life are met it will have a significant effect on improving employee performance. In this research, it shows that the cost of living can encourage employee performance improvement through wage policies.

\section{CONCLUSION AND SUGESTION}

Whereas government regulations on wage policies for Indonesia are very dominant, then the wage policy through the Manpower Act every year has always increased through the determination of Wages. The aim of the government to participate in regulating and establishing wage standards is to prevent exploitation and exploitation of labor by employers. To protect groups of workers from low wage levels, so that the wages set by employers can provide satisfaction, as well as to achieve employee employment and improve living standards. Government regulations can encourage employee performance improvements through wage policies. If the wage policy is implemented in accordance with government regulations, it will indirectly increase the performance of employees who are in companies in the industrial area of Bekasi Regency.

The role of trade unions is considered good because it has a positive and significant effect on employee welfare. Companies in the Bekasi Regency industrial area also have the same role as other trade unions, namely playing a defensive role in increasing the income of their members by applying good pressure to the government, which in this case has a role in making policies in determining the level of compensation and also the trade union to emphasize for companies to always pay attention to wage levels related to wage policies. The role of trade unions in employee performance is that if the union is able to negotiate well with the company, it will lead to better changes in employee performance. Workers Unions on Employee Performance through Wage Policies. That trade unions can indirectly improve employee performance through demands for changes to better wage policies. If the wage policy is determined fairly, it will cause significant changes in employee performance.

Labor productivity is a management tool at all levels of the economy. Work productivity is used to help evaluate appearance, planning, income, wages and price policies through the identification of factors that affect the distribution of income. Productivity measurement is mainly used as a management tool to analyze and promote production efficiency. So that in this study shows that work productivity can encourage employee performance improvement through wage policies. Work productivity can affect employee performance indirectly through wage policies, if the wage policy changes higher, it can cause significant changes to employee performance. So that in this study shows that work productivity can encourage employee performance improvement through wage policies.

In companies in the Bekasi Regency Industrial Estate, the cost of living in Bekasi Regency is considered quite high, such as ownership of a house, transportation costs, food costs and so on. The wages received are not sufficient to have a place to live because the 
price is quite high, not to mention the cost of food, transportation and so on, so the cost of living really encourages the determination of the level of wages according to the needs of a decent life. The higher the cost of living, the higher the demands for wage level adjustments must refer to the fulfillment of the needs of a decent life, if the needs of a decent life are met it will have a significant effect on improving employee performance. In this research, it shows that the cost of living can encourage employee performance improvement through wage policies.

For company development and improvement of employee performance through wage policies, the researchers suggest that government policies, trade unions, work productivity and living costs have a significant effect on wage policies. which greatly influences it, so that the wage policy can have a good impact on the company and also employee performance.

In terms of improving employee performance, the researchers found that government regulations, labor unions and work productivity, as well as wage policies directly affect employee performance with significant results. This can be a concern for the company to improve employee performance as well as pay attention to the factors that influence it, so that it can have a good impact on the company and employees.

\section{REFERENCE}

Adnan, A., \& Saragih, R. (2019). PENGARUH DISIPLIN KERJA DAN PRODUKTIVITAS KERJA TERHADAP KINERJA KARYAWAN BADAN METEOROLOGI KLIMATOLOGI DAN GEOFISIKA (BMKG) JAKARTA, ISSN : 2355-9357. EProceeding of Management, 6(2), 4191-4197.

Anoraga, P. (2009). Manajemen Bisnis. PT. Rineka Cipta.

Boje, T. P. and B. F. (2003). Post-Industrial Labour Markets, Profiles of North America and Scandinavia. Routledge.

Budiarti. (2008). Serikat Pekerja (on strike unfair labor practice). PSI Coordinator Indonesia. Edy Sutrisno. (2009). Manajemen Sumber Daya Manusia.Edisi Pertama (K. P. M. Group. (ed.)).

Efendi, F., \& Sastra Tamami. (2017). Pengaruh Tingkat Upah, Kesejahteraan, Dan Loyalitas Terhadap Kinerja Karyawan Pada Pt. Angkasa Engineers Indonesia. Equilibiria FEUniversitas Riau Kepulauan Batam, 4(1).

Frandsen, B. R. (2012). Why Unions Still Matter: The Effects of Unionization on the Distribution of Employee Earnings. MIT Economics, 1-145.

Geby Alvita, Ari Pradhanawati, \& Reni Shinta Dewi. (2014). Pengaruh Peran Serikat Pekerja dan Kompensasi Terhadap Kesejahteraan Buruh Wanita Studi Kasus di PT. Hanil Indonesia. Diponegoro Journal Of Social And Political Of Science, 1-9. http://ejournals1.undip.ac.id/index.php/

Hakim, A. (2006). Analisis Pengaruh Motivasi, Komitmen Organisasi Dan Iklim Organisasi Terhadap Kinerja Pegawai Pada Dinas Perhubungan Dan Telekomunikasi Provinsi JawaTengah. JRBI, 165-180.

Handoko, T. H. (2006). Manajemen Personalia dan Sumberdaya Manusia. BPFE.

Havidatun Nadziroh Al Ghozali dan Sandi Eka Suprajang. (2017). Peningkatan Kinerja Karyawan melalui Penetapan Gaji pada UD Mega Grosir (Mega Group) Kota Blitar. Penelitian Manajemen Terapan (PENATARAN), 2(2).

Ibrahim JK, \& Ismi D. (2010). Pelaksanaan Program Keselamatan dan Kesehatan Kerja Karyawan PT. Bitratex Industries Semarang.

Indrasari Tjandraningsih, R. H. (2009). Menuju Upah layak survai Upah Buruh Tekstil dan 


\section{Garmen di Indonesia.}

Kanzunnudin, M. (2007). Effect of wages and supervision of employee productivity: A case Study on PT Tonga Tiur Son Zenith District Kragan. Fokus Ekonomi, 2(1), 11-20.

Kasiram, M. (2006). Metodologi Penelitian: Refleksi Pengembangan Pemahaman dan Penguasaan Metodologi Penelitian. UIN Maliki Press.

Ketut Alit Wiantara. (2015). Hubungan Tingkat Upah Dengan Produktivitas Kerja Pada Perusahaan Kecap Sumber Rasa Di Desa Temukus Tahun 2014. Jurusan Pendidikan Ekonomi, FEB Universitas Pendidikan GaneshaSingaraja, Indonesia, 5(1).

Kirdi Dipoyudo. (2005). Keadilan Sosial. CV. Rajawali.

Klein, N. (2012). Real Wage, Labor Productivity, and Employment Trens in south Africa: A Closer Look",.

Kurniawan, S., \& Sulistyaningrum, E. (2017). Dampak Serikat Buruh Terhadap Tingkat Upah Buruh Sektor Swasta di Indonesia, pISSN : 2301 - 8968 eISSN : 2303 0186. JURNAL EKONOMI KUANTITATIF TERAPAN, 10(2).

Mangkunegara, A. P. (2005). Evaluasi Kinerja Sumber Daya Manusia. Refika Aditama.

Mankiw n Gregory. (2006). Principles Of Economics Pengantar Ekonomi Makro. Salemba Empat.

Mathis, R. ., \& J.H. Jackson. (2006). Human Resource Management: Manajemen Sumber Daya Manusia. Terjemahan Dian Angelia. Salemba Empat.

Megawati Maulidyah Jaenudin, \& Alini Gilang. (2015). Analisis Faktor-Faktor Yang Berperan Dalam Penentuan Kompensasi Karyawan Pada Telkomedika Bandung. EProceeding of Management, 2(2).

Michael C. Sturman, Andrey D. Ukhov, \& Anghee Park. (2017). The Effect of Cost of Living on Employee Wages inthe Hospitality Industry. Cornell University School of Hotel AdministrationThe Scholarly Commons.

Mulyadi. (2001). Akuntansi Manajemen : Konsep, Manfaat dan Rekayasa. Salemba Empat.

Nadziroh, Havidatun Al Ghozali, \& Sandi Eka Suprajang. (2017). Peningkatan Kinerja Karyawan melalui Penetapan Gaji pada UD Mega Grosir (Mega Group) Kota Blitar. Jurnal Penelitian Manajemen Terapan (PENATARAN), 2(2), 107-118.

Noto Atmodjo, S. (2003). Pengembangan Sumber Daya Manusia, Cetakan Ke-2. Reneka Cipta.

Nurhidayati. (2016). Indisipliner Jadi Alasan Maraknya PHK di Kabupaten Bekasi. http://dakta.com/news/6391/indisipliner-jadi-alasan-maraknya-phk-di-kabupaten-bekasi

Qianqian Huang, Feng Jiang, Erik Lie, \& Tingting. (2017). Que The Effect of Labor Unions on CEO Compensation. Journal Of Financial And Quantitative Analysis, 52(2).

Rachbini, W., \& Didik J.Rachbini. (2020). Metode Riset Ekonomi \& Bisnis ( Analisis Regresi-SPSS \& SEM-Lisrel. INDEF.

Rios-Avila, F. (2013). Essays on Unions, Wages and Performance: Evidance from Latin America. Departement of Economics Georgia State University. Economics Dissertations, 1-155.

Rivai, V., \& Basri. (2005). Peformance Appraisal: Sistem yang tepat untuk Menilai Kinerja Karyawan dan Meningkatkan Daya Saing Perusahan. PT. RajaGrafindo Persada.

Sedarmayanti. (2004). Manajemen Sumber Daya Manusia. Bumi Aksara.

Simon, H. A. (2007). Administrasi Behavior: Perilaku Administrasi Studi tentang Proses Pengambilan keputusan dalam Organisasi Administrasi . Bumi Aksara.

Suleman, D. (2018). Faktor Penentu Keputusan Konsumen Indonesia MemilihTempat Belanja Disebuah E-Commerce (Theory of Planned Behavior). Jurnal JDM, I(02), 1-9. http://journal.mercubuana.ac.id/index.php/jdm/article/view/4120

Suleman, D., Ali, H., Nusraningrum, D., \& Ali, M. M. (2020a). Consumer Behaviour in the Marketing 4.0 Era Regarding Decisions about Where to Shop. International Journal of 
Innovation, Creativity and Change, 13(7), Pp: 444-456. https://www.ijicc.net/images/vol_13/Iss_7/13763_Suleman_2020_E_R.pdf

Suleman, D., Ali, H., Nusraningrum, D., \& Ali, M. M. (2020b). Consumer Factors in Choosing Shopping Place in 4.0. JURNAL MANAJEMEN DAN BISNIS SRIWIJAYA, 17(4), 193-198. $\quad$ https://doi.org/DOI: https://doi.org/10.29259/jmbs.v17i4.11529

Suleman, D., Ali, H., Nusraningrum, D., \& Ali, M. M. (2020c). Strategi memenangkan persaingan bisnis berbasis perilaku konsumen untuk produk fashion. Lembaga pendidikan dan pelatihan balai insan cendekia.

Suleman, D., Ali, H., Nusraningrum, D., \& Ali, M. M. A. (2019). Perceived Ease of Use, Trust and Risk toward Attitude and Intention in Shopping for Online Fashion Products In Indonesia. Archives of Business Research, Vol.7(No.4), pp.240-253. https://doi.org/DOI: http://dx.doi.org/10.14738/abr.74.2019

Sujarweni, V. W. (2014). Metode Penelitian: Lengkap, Praktis, dan Mudah Dipahami. Pustaka Baru Press.

Sukirno Sadono. (2013). Makro Ekonomi Teori Pengantar Edisi Ketiga. PT. Raja Grafindo Persada.

Sutrisno, E. (2009). Manajemen Sumber Daya Manusia. Kencana Prenada Media Group.

T. Gilarso. (2003). Pengantar Ilmu Ekonomi Mikro. Kanisius.

Umar, Husen, Dr, P. (2008). Desain Penelitian MSDM dan Perilaku Karyawan Paradigma Positifistik dan Berbasis Pemecaran Maslah. Rajawali Pers.

Umar, H. (2001). Riset Sumber Daya Manusia Dalam Organisasi. Gramedia Pustaka Utama.I

Wahyuningtyas, B. (2014).Bounded Rationality Studi Deskripti Tentang Konflik Kepentingan dalam Perumusan Upah Minimum Kabupaten (UMK) Gresik, Kebijakandan Manajemen Publik. 2.

Winters, J. V. (2009). Wages and prices: Are workers compen-sated for cost of living differences? Regional Science and Urban Economics, 39, 632-643.

Yuli, S. B. C. (2005). Manajemen Sumber Daya Manusia. UMM Press.Malang. Yuniarsih

Tjutju, S. (2009). Manajemen Sumber DayaManusia. Alvabeta. 